\title{
The Colonization of a Cold Spring Ecosystem by the Invasive Species Potamopyrgus antipodarum (Gray, 1843) (Gastropoda: Tateidae) (Southern Poland)
}

\author{
Mariola Krodkiewska *, Anna Cieplok and Aneta Spyra (D) \\ Faculty of Natural Sciences, Institute of Biology, Biotechnology and Environmental Protection, University of \\ Silesia, 40-007 Katowice, Poland; anna.cieplok@us.edu.pl (A.C.); aneta.spyra@us.edu.pl (A.S.) \\ * Correspondence: mariola.krodkiewska@us.edu.pl
}

\section{check for} updates

Citation: Krodkiewska, M.; Cieplok, A.; Spyra, A. The Colonization of a Cold Spring Ecosystem by the Invasive Species Potamopyrgus antipodarum (Gray, 1843) (Gastropoda: Tateidae) (Southern Poland). Water 2021, 13, 3209. https://doi.org/ 10.3390/w13223209

Academic Editors:

Lyudmila Kamburska,

Agnese Marchini and Hugh MacIsaac

Received: 30 September 2021

Accepted: 8 November 2021

Published: 12 November 2021

Publisher's Note: MDPI stays neutral with regard to jurisdictional claims in published maps and institutional affiliations.

Copyright: (c) 2021 by the authors. Licensee MDPI, Basel, Switzerland. This article is an open access article distributed under the terms and conditions of the Creative Commons Attribution (CC BY) license (https:/ / creativecommons.org/licenses/by/ $4.0 /)$.

\begin{abstract}
Springs are unique aquatic environments that support specific biota, including endemic species and rare species listed in Red Lists. Due to their usually small size, springs are highly sensitive to disturbance. Many of them are threatened by aquifer depletion, contamination, surface-water diversion, livestock trampling, recreation, and invasive species. The aim of this study was to assess the colonization success of the invasive New Zealand mud snail (Potamopyrgus antipodarum) in a cold spring ecosystem in southern Poland. In Europe, this species has recently been added to the top "hundred worst" alien species due to its impact on invaded ecosystems. The study was carried out in two areas of the spring ecosystem —in the springhead and the springbrook—over a four-year period. Potamopyrus antipodarum dominated the benthic macroinvertebrate communities in both areas of the spring ecosystem. Nevertheless, its abundance in the springbrook was significantly greater, and increased noticeably during subsequent years compared to that in the springhead. The populations of $P$. antipodarum were exclusively composed of females. Smaller-sized New Zealand mudsnails were more abundant near the spring's source than at the second site. The females at the springhead became fecund at sizes as small as $3.7 \mathrm{~mm}$ (the number of embryos was between 0 and 37), while at the springbrook, embryos were found in snails as small as $3.4 \mathrm{~mm}$ (the number of embryos was between 0 and 42). Our results suggest that the lower water temperature at the springhead may limit the population size of $P$. antipodarum, thus making its density too low to be able to affect the community structure of benthic macroinvertebrates, including the spring snail Bythinella cf. austriaca.
\end{abstract}

Keywords: invasive alien species; cold spring ecosystem; spring fauna; spring threats

\section{Introduction}

Springs are unique and usually isolated ecosystems that are at the interface between groundwater and surface water. They can be considered ecotones that link terrestrial and aquatic ecosystems and groundwater and surface water [1-3]. Springs are often described as ecosystems with relatively constant conditions, both physical and chemical [1], changing rapidly with distance from the crop out [4].

Springs are usually very small in size, but occur in large numbers [3]. Due to their specific conditions, they are inhabited by well-defined biocoenoses [5-7]. Some species are found only in springs (crenobionts) [1,8], while others inhabit springs and other comparable aquatic habitats (crenophiles) [9,10]. As a result of isolation, gene flow between springs is limited, which can lead to their considerable biodiversity and high levels of endemism [11]. They are often inhabited by relict species [12,13]. Examples of endemic fauna that have evolved and diversified using unique spring habitats include high numbers of pupfish species inhabiting North American desert springs [14], or snail species associated with springs in Australia [15].

The mosaic of microhabitat and high degree of individuality make springs significant contributors to local and regional biodiversity $[3,13,16,17]$. As they can be headwater 
stream, they can contribute to the biodiversity of entire river networks [18]. Springs and spring-fed habitats are recognized as biodiversity hotspots that support unique aquatic species communities around the world $[2,9,19]$. The waters of many springs are of high quality and thus provide suitable habitats for rare species due to their sensitivity to anthropogenic influences. Springs are often species-rich and contain a greater number of Red List taxa than other aquatic habitats [7]. In protected areas in the European Alps, Red List diatom species typically account for $40-50 \%$ of crenic species [7,20-22]. In Finland, Ilmonen et al. [9] found a high number of red-listed bryophyte and macroinvertebrate species in undisturbed springs compared to springs influenced by forest management and melioration.

Due to their small size, springs are highly sensitive to disturbance, and many of them are threatened by, among other things, aquifer depletion, contamination, surface-water diversion, livestock trampling, recreation, invasive species and results from surrounding landscape disruptions [23-26]. Alien species can have significant effects on the biodiversity and ecological functions of springs. Exotic plants can reduce overall plant and animal diversity and alter site hydrology, while alien animals can reduce or even destroy native aquatic species [27-29]. Invasive species can compete with endemic spring biota as a result of habitat alteration (e.g., non-native plant species) [30], competition and predation [31,32]. Colonization of a spring complex in central western Queensland, Australia, by the invasive mosquito fish Gambusia holbrooki has led to population declines and local extinctions of the endemic and critically endangered fish Scaturiginichthys vermeilipinnis [33,34]. As a result, this species was included on the list of the 100 most endangered species in the world [35]. The native flora and fauna of springs in California and Nevada suffered from stocking with sportfish and bait $[36,37]$ and introduced aquarium fish, mostly cichlids, and invertebrates among other Melanoides snails, frequent occurred in springs of Nevada and Mexico [38,39]. The risk of invasion by exotic species increases in springs with greater human disturbance $[40,41]$. For example, livestock farming can facilitate the colonization of non-native plants by both removing native species and supporting vectors that provide propagules of exotic plants [42].

Potamopyrgus antipodarum (Gray, 1843; Gastropoda, Tateidae), native to New Zealand, is a snail that has successfully invaded fresh and brackish waters throughout the world. To date, it has been found in Europe, Asia, North America and Australia [43]. In recent years, P. antipodarum has also been found in South America [44] and Africa [45]. To date, only in Antarctica are there no data on its occurrence. In Europe, P. antipodarum has recently been added to the top "hundred worst" alien species, among which it is the third "worst alien" mollusc, after Dreissena polymorpha and Pomacea canaliculata [46].

The high tolerance to a wide range of physical and chemical conditions, high reproductive rate [43,47], high tolerance to air exposure [48], ability to survive in non-aquatic media for example attach to sediment and clay which allows overland translocation and spreading [49], capacity to spread via various mechanisms and lack of natural predators and parasites within new ecosystems $[43,47]$ are considered to be the reasons for the invasive success of the New Zealand mud snail. It also has a variety of ways of dealing with potential enemies and parasites and is weakly affected by parasites [50-52]. In the invaded range of P. antipodarum, no infected snails were found in Belgium, Germany and the Netherlands [53,54], and only very low percentages in Poland [55,56], the USA [57,58], France [50,59,60], the United Kingdom (UK) [61] and Australia [62]. Verhaegen et al. [54] suggest adding early sexual maturity and the adaptation of size at sexual maturity to the list of functional traits explaining the invasive success of P. antipodarum.

The impact of the New Zealand mud snail in established ecosystems varies across habitats, which can be explained by the different densities the snail can achieve [43]. For example, in Australia, a positive relationship has been noted between P. antipodarum abundance and native benthic fauna [63], while in the USA and Chile, a negative impact on endemic macroinvertebrate communities has been indicated [64], as well as on gastropods [65-68]. Despite the fact that P. antipodarum can dominate mollusc assemblages in 
Europe, only a low impact on macroinvertebrate communities has been documented to daste $[69,70]$. In very high abundance, P. antipodarum can modify the structure of native communities and change the functioning of entire ecosystems, including controlling the carbon and nitrogen cycles, alga and invertebrate communities [71-73]. Additionally, it is rarely eaten by most benthivorous fishes, and can even survive passing through their digestive tracts, and therefore, there is a justified concern that its invasion may limit the flow of primary production towards a higher trophic level [52,74-76]. In other cases, it can integrate into the host assembly and cause no obvious harmful effect $[46,69,77]$.

Outside its natural range, $P$. antipodarum has been reported in various types of freshwater ecosystems (streams, rivers, lakes, ponds, artificial lakes, reservoirs etc.) and saltwater ecosystems (estuaries, polder-marshes etc.) [47]. It has also colonized very peculiar habitats such as a sulfidic spring and a sulfidic phreatic pool near the entrance to the Grotta del Fiume in Italy [78], an underground water pipe in Grummount Road, Peckham, South London and the thresholds of some caves and mines around Morecambe Bay, England and the Isle of Man [79]. In general, the New Zealand mud snail can likely establish itself successfully at sites around the world that have similar conditions to that in its native area [77]. As a general rule, human-disturbed ecosystems are more vulnerable to a $P$. antipodarum invasion because they open new niches for invaders that are more adaptable compared to pristine ecosystems [50,77,80-83].

Beyond its native range, P. antipodarum is generally less frequently established in springs. It has previously been observed in springs in the Spanish province of Cuenca [84], in springs in the British Isles [85] and in Banbury Springs (a tributary of the Snake River) near Hagerman, ID, USA [86]. According to Hinz et al. [84], it inhabits brooks and rivers more often than springs.

In the summer of 2011, during a routine sampling for macroinvertebrates in the springs in the eastern part of the Silesian Upland (the Katowice Upland, southern Poland) a small population of New Zealand mud snails was detected in one of the springs. Unfortunately, previous studies on the composition of benthic fauna in this spring $[87,88]$ were only carried out at the family or subfamily level, which made it impossible to determine whether P. antipodarum (this species was previously classified in the family Hydrobiidae, but it was recently included in the family Tateidae see Wilke et al. [89]) had become established at that time. This finding (to the best of our knowledge, the first locality record in springs in Poland) provides the opportunity (1) to assess the colonization of a spring ecosystem by this invasive snail species; (2) to evaluate its abundance, the population structure and the fecundity; and (3) to examine the change in the structure of benthic macroinvertebrate communities.

\section{Material and Methods}

\subsection{Study Area}

The spring in which the New Zealand mud snails were found is situated in the middle of a small park in Strzemieszcze Wielkie, a district of the city of Dabrowa Górnicza (the Katowice Upland, southern Poland) (Figure 1a). It flows with a discharge of about $50 \mathrm{~s}^{-1}$ from the bottom of a small pond (surface area: $972 \mathrm{~m}^{2}$ ) with banks partially physically modified by concrete structures (see Figure $1 b$ ). The water next flows through a concrete culvert into another small pond (surface area: $664 \mathrm{~m}^{2}$ ) (Figure 1c) and then empties into a creek of the Rakówka Stream (a right-bank side tributary of the Bobrek Stream, a tributary of the Biała Przemsza River). 


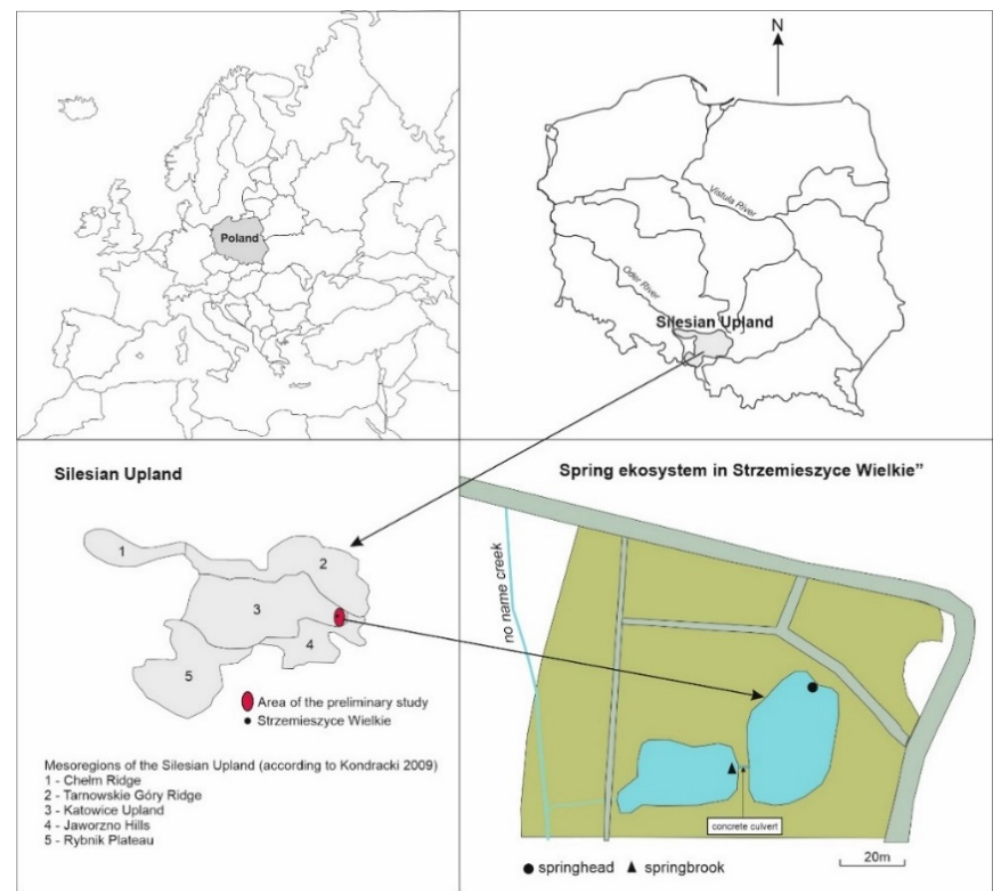

(a)

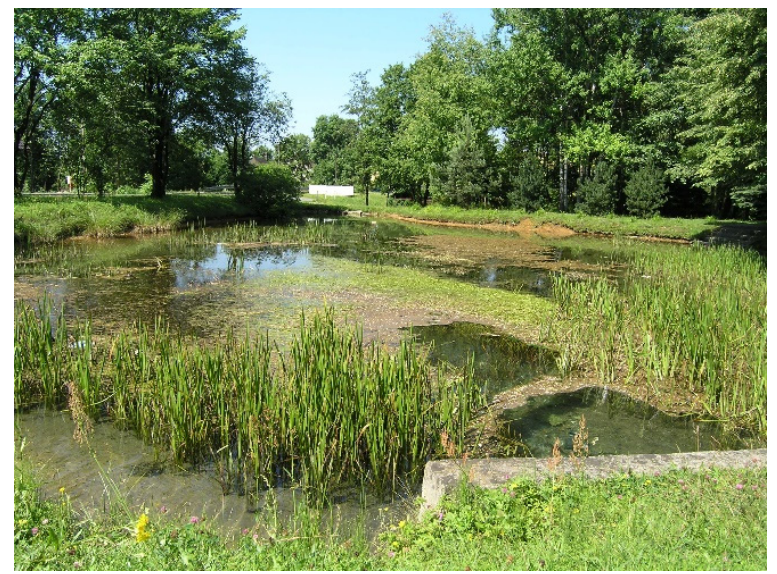

(c)

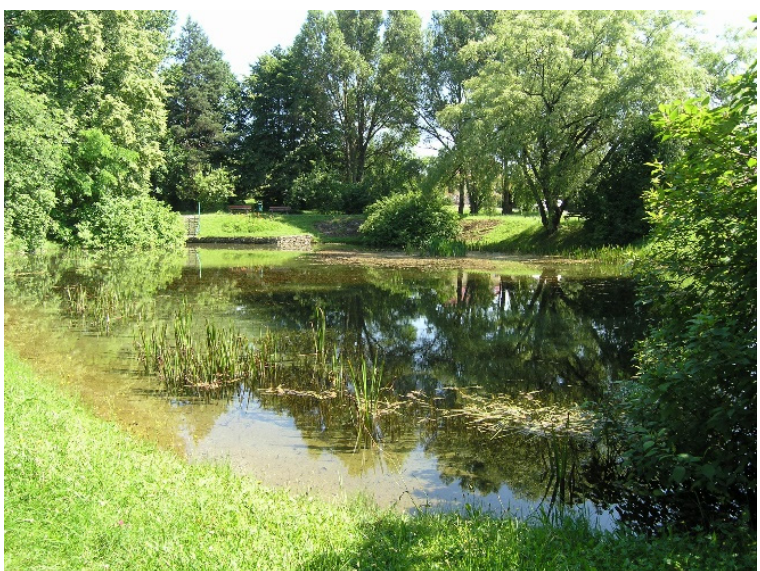

(b)

Figure 1. (a) Location of the study area; (b) spring in the bottom of a pond in Strzemieszyce Wielkie; (c) pond into which waters from the spring flow.

According to the ecomorphological classification of springs based on current velocity conditions [90,91], it is a rheocrenic spring (springs with rapid currents such as those in streams). It is located on a Triassic limestone and dolomite bedrock in a valley of the Biała Przemsza River [92].

In the 19th century, during the period of the development of the mining industry, the spring water was used in the processes of washing lead ore and iron ore. Since 1996, the spring has been protected by Polish law as the natural monument "Wywierzyska in Strzemieszyce Wielkie" due to its unique spring biota (the permit for sample collection was provided by the Dąbrowa Górnicza City Hall-WER. 6121.6.2012. MW (Dąbrowa Górnicza, Poland).

\subsection{Sampling Procedure}

The study was carried out in two areas of the spring ecosystem: in the springhead (eucrenal), and in the springbrook, which forms an encased pond (hypocrenal). For the 
research, the spring area was divided into two sections with the boundary of the springhead at the point at which the water temperature varies from the temperature at the source by $2{ }^{\circ} \mathrm{C}$ [93] or at $5 \mathrm{~m}$ downstream from the source [94]. The first sampling area was situated in the immediate vicinity of the spring's source (within $1 \mathrm{~m}$ of the source) and the other was located at a distance of about $40 \mathrm{~m}$ from the source (Table 1; Figure 1a).

Table 1. Characteristics of the spring and the sampling sites.

\begin{tabular}{|c|c|c|}
\hline Characteristic & \multicolumn{2}{|c|}{ Description } \\
\hline Type of a spring & \multirow{2}{*}{\multicolumn{2}{|c|}{$\begin{array}{l}\text { valley, rheocrene, in the bottom of the pond } \\
50\end{array}$}} \\
\hline Discharge $\left(1 \mathrm{~s}^{-1}\right)$ & & \\
\hline Drainage basin of a river & \multicolumn{2}{|c|}{ Przemsza } \\
\hline Altitude & \multicolumn{2}{|c|}{$290 \mathrm{~m}$ a.s.l. } \\
\hline Geographical location & \multicolumn{2}{|c|}{ Katowice Upland } \\
\hline Geographical coordinates & \multirow{2}{*}{\multicolumn{2}{|c|}{$\begin{array}{c}\mathrm{N} 50^{\circ} 18.399^{\prime} \text { E } 19^{\circ} 19.422^{\prime} \\
\text { natural monument named "Wywierzyska in } \\
\text { Strzemieszyce Wielkie" }\end{array}$}} \\
\hline Management & & \\
\hline \multirow[t]{2}{*}{ Range of water temperature $\left({ }^{\circ} \mathrm{C}\right)$} & \multicolumn{2}{|c|}{$9.0-11.0$} \\
\hline & springhead & springbrook \\
\hline Location & $\begin{array}{l}\text { within } 1 \mathrm{~m} \text { of the spring's } \\
\text { source }\end{array}$ & within $40 \mathrm{~m}$ of the source \\
\hline Dominant type of substrate & loamy sand & loamy sand \\
\hline Aquatic macrophytes & none & $\begin{array}{l}\text { Sparganium erectum L., } \\
1753\end{array}$ \\
\hline
\end{tabular}

The number of samples had to be restricted to one per year due to the protection of the spring by Polish law, its small surface area, and the possibility of destroying the spring environment. At each sampling area, macroinvertebrates were collected in June from 2012 to 2015 using a cuboid metal frame with Plexiglass sides (frame dimensions: W $25 \mathrm{~cm} \times \mathrm{D} 25 \mathrm{~cm} \times \mathrm{H} 50 \mathrm{~cm}$ ). The frame was placed into the substratum by hand and the topmost $5 \mathrm{~cm}$ of sediment was moved into a labeled plastic container using a shovel. At each sampling area, sediments from five randomly placed frames were pooled together in the container and constituted one composite sample. In the laboratory, the sediments were sieved using a $0.5 \mathrm{~mm}$ mesh sieve. The macroinvertebrates that remained on the sieve were sorted under a dissecting microscope and then preserved in an $80 \%$ ethanol solution.

The majority of faunal groups were identified to the family level with the exception of gastropods and crustaceans, which were identified to the species level using the keys of Glöer [95] for Gastropoda and Eggers and Martens [96] for Amphipoda.

Water temperature, conductivity, $\mathrm{pH}$, concentration of total dissolved solids (TDS) and dissolved oxygen were measured in situ using Hanna Instruments portable meters at the same time as the macroinvertebrates were collected. Furthermore, water samples were collected in plastic bottles for the analyses of other parameters. Nitrates, ammonium, phosphates, chlorides, total hardness, alkalinity, calcium, magnesium and iron were analyzed in the laboratory according to the standard methods of Hermanowicz et al. [97].

From both sampling sites, the shell length (measured from the apex of the shell to the anterior edge of the aperture) of all of the collected specimens was measured to the nearest $0.1 \mathrm{~mm}$ using a stereoscopic microscope equipped with a camera and cellSens Standard 1.4 software to determine the size structure of the P. antipodarum populations. The entire size range of shell lengths was divided into five (1mm-distanced) classes.

The fecundity of P. antipodarum, which was based on the number of embryos in a brood pouch, was assessed for 30 specimens from each sampling site in each year of the study. In total, 240 snails were analyzed. For this study, we selected snails whose shell length was no less than $3.0 \mathrm{~mm}$, because $P$. antipodarum reaches sexual maturity at a length of $3.0 \mathrm{~mm}[98,99]$. 


\subsection{Data Analysis}

The taxonomic composition of the macroinvertebrate communities was assessed using the non-metric multidimensional scaling (NMDS) ordination method. The macroinvertebrate abundance data were $\log (\mathrm{x}+1)$ transformed and rare taxa (those that occurred in only one sample) were removed from the analysis in order to reduce the noise in the data set [100]. In the NMDS method, the Bray-Curtis was applied as the distance measure to calculate any dissimilarity among the samples. The strength of the ordination was assessed by stress value. The importance of the environmental variables in explaining the structure of the macroinvertebrate communities was tested by Pearson correlation $(\mathrm{r})$ with the sample scores of NMDS dimension. CANOCO for Windows version 5.0 was used for the NMDS [101].

The mean shell length of P. antipodarum and the mean number of embryos in a brood pouch were compared between the sampling areas using the t-test. A one-way analysis of variance (ANOVA) was performed for the shell length and the number of embryos in a brood pouch between the years of the study period for each sampling site. The relationships between the shell length of P. antipodarum and the number of embryos in a brood pouch was explored using the Pearson correlation coefficient. All of these statistical analyses were performed using Statistica version 13.1. Factors with a $p<0.05$ were considered to be significant.

\section{Results}

\subsection{Water Chemistry}

Most of the water properties were similar at the sampling sites. At both areas of the spring ecosystem, the water was hard, rich in magnesium (calcium-magnesium waters), and well oxygenated, with $\mathrm{pH}$ close to neutral values (ca. pH 7) (Table 2). The sampling sites only varied with respect to water temperature. The water was approximately $4{ }^{\circ} \mathrm{C}$ colder at the springhead compared to that at the springbrook (Table 2).

Table 2. Water parameters of the sampling sites in the spring ecosystem.

\begin{tabular}{|c|c|c|c|c|c|}
\hline \multirow{2}{*}{ Parameter } & \multirow{2}{*}{ Site } & \multicolumn{4}{|c|}{ Year } \\
\hline & & 2012 & 2013 & 2014 & 2015 \\
\hline \multirow[t]{2}{*}{ Temperature $\left({ }^{\circ} \mathrm{C}\right)$} & $\mathrm{SH}$ & 10.1 & 9.9 & 10.0 & 10.1 \\
\hline & SB & 14.1 & 13.9 & 14.0 & 14.2 \\
\hline \multirow[t]{2}{*}{ Dissolved oxygen $\left(\mathrm{mg} \mathrm{L}^{-1}\right)$} & $\mathrm{SH}$ & 7.7 & 7.8 & 7.9 & 7.7 \\
\hline & SB & 7.6 & 7.6 & 7.8 & 7.3 \\
\hline \multirow[t]{2}{*}{$\mathrm{pH}$} & $\mathrm{SH}$ & 7.2 & 7.3 & 7.6 & 7.3 \\
\hline & SB & 7.3 & 7.7 & 7.7 & 7.4 \\
\hline \multirow{2}{*}{ Conductivity $\left(\mu \mathrm{S} \mathrm{cm}^{-1}\right)$} & $\mathrm{SH}$ & 720 & 799 & 760 & 830 \\
\hline & SB & 770 & 798 & 740 & 810 \\
\hline \multirow[t]{2}{*}{ Total dissolved solids (mg L ${ }^{-1}$ ) } & $\mathrm{SH}$ & 460 & 520 & 370 & 410 \\
\hline & SB & 380 & 518 & 360 & 400 \\
\hline \multirow{2}{*}{ Chlorides (mg L $\left.{ }^{-1}\right)$} & $\mathrm{SH}$ & 60 & 40 & 42 & 46 \\
\hline & SB & 60 & 46 & 44 & 40 \\
\hline \multirow[t]{2}{*}{ Nitrate nitrogen $\left(\mathrm{mg} \mathrm{L}^{-1}\right)$} & $\mathrm{SH}$ & 2.1 & 4.6 & 7.2 & 5 \\
\hline & SB & 4.2 & 4.4 & 5.2 & 8.4 \\
\hline \multirow[t]{2}{*}{ Ammonium nitrogen $\left(\mathrm{mg} \mathrm{L}^{-1}\right)$} & $\mathrm{SH}$ & 0.16 & 0.09 & 0.5 & 0.1 \\
\hline & SB & 0.17 & 0.1 & 0.05 & 0.21 \\
\hline \multirow{2}{*}{ Phosphates (mg L $\left.{ }^{-1}\right)$} & $\mathrm{SH}$ & 0.14 & 0.11 & 0.08 & 0.08 \\
\hline & SB & 0.14 & 0.13 & 0.07 & 0.1 \\
\hline \multirow{2}{*}{ Total hardness $\left(\mathrm{mgCaCO}_{3} \mathrm{~L}^{-1}\right)$} & $\mathrm{SH}$ & 435 & 501.9 & 405 & 355 \\
\hline & SB & 435 & 494.7 & 325 & 355 \\
\hline \multirow[t]{2}{*}{ Calcium (mg L $\left.{ }^{-1}\right)$} & $\mathrm{SH}$ & 86.0 & 104.0 & 102.0 & 100.0 \\
\hline & SB & 86.0 & 108.0 & 92.0 & 120.0 \\
\hline \multirow{2}{*}{ Magnesium (mg L $\left.{ }^{-1}\right)$} & $\mathrm{SH}$ & 53.5 & 58.8 & 46.5 & 45.6 \\
\hline & $\mathrm{SH}$ & 53.5 & 54.7 & 53.1 & 53.4 \\
\hline \multirow[t]{2}{*}{ Alkalinity $\left(\mathrm{mgCaCO}_{3} \mathrm{~L}^{-1}\right)$} & SB & 285 & 250 & 235 & 290 \\
\hline & $\mathrm{SH}$ & 240 & 240 & 215 & 285 \\
\hline \multirow{2}{*}{ Iron $\left(\mathrm{mg} \mathrm{L}^{-1}\right)$} & SB & 0.02 & 0.05 & 0.02 & 0.01 \\
\hline & SB & 0.02 & 0.05 & 0.18 & 0.03 \\
\hline
\end{tabular}




\subsection{Macroinvertebrate Communities}

At the springhead, the benthic macroinvertebrate community was composed of nine higher taxonomical groups (Gastropoda, Bivalvia, Crustacea, Oligochaeta, Plecoptera, Trichoptera, Coleoptera, Diptera, Turbellaria), among which gastropods and crustaceans dominated (more than $80 \%$ of the total benthic fauna) (Table 3). At the springhead, the gastropods were represented by two species-native Bythinella cf. austriaca and exotic Potamopyrgus antipodarum - while Gammarus fossarum and Asellus aquaticus represented crustaceans. The density of P.antipodarum changed slightly throughout the period of the study and was no greater than 4700 specimens per $\mathrm{m}^{2}$ (Figure 2), and its share in the assemblage was no greater than $20 \%$ (Table 3). The abundance and share of other macroinvertebrates in the benthic macroinvertebrate community did not change significantly (Table 3, Figure 2).

Table 3. Macroinvertebrate taxa at the sampling sites ( $n$-number of individuals, $\%$-percentage share).

\begin{tabular}{|c|c|c|c|c|c|c|c|c|c|c|c|c|c|c|c|c|c|c|}
\hline \multirow{3}{*}{ Higher Taxa } & \multirow{3}{*}{ Family } & \multirow{3}{*}{ Species } & \multicolumn{8}{|c|}{ Springhead } & \multicolumn{8}{|c|}{ Springbrook } \\
\hline & & & \multicolumn{2}{|c|}{2012} & \multicolumn{2}{|c|}{2013} & \multicolumn{2}{|c|}{2014} & \multicolumn{2}{|c|}{2015} & \multicolumn{2}{|c|}{2012} & \multicolumn{2}{|c|}{2013} & \multicolumn{2}{|c|}{2014} & \multicolumn{2}{|c|}{2015} \\
\hline & & & $n$ & $\%$ & $n$ & $\%$ & $n$ & $\%$ & $n$ & $\%$ & $n$ & $\%$ & $n$ & $\%$ & $n$ & $\%$ & $n$ & $\%$ \\
\hline \multirow[t]{5}{*}{ Gastropoda } & Tateidae & $\begin{array}{l}\text { Potamopyrgus } \\
\text { antipodarum } \\
\text { (Gray, 1843) }\end{array}$ & 468 & 20.0 & 398 & 19.1 & 419 & 18.8 & 589 & 19.9 & 579 & 64.0 & 706 & 69.5 & 828 & 69.0 & 2303 & 86.1 \\
\hline & Bythinellidae & $\begin{array}{c}\text { Bythinella cf. } \\
\text { austriaca (v. } \\
\text { Frauenfeld 1857) }\end{array}$ & 478 & 20.5 & 410 & 19.7 & 435 & 19.6 & 625 & 21.1 & 19 & 2.1 & 14 & 1.4 & 9 & 0.8 & 4 & 0.1 \\
\hline & Lymnaeidae & $\begin{array}{c}\text { Radix balthica } \\
\text { (Linnaeus, 1758) }\end{array}$ & & & & & & & & & & & & & 5 & 0.4 & & \\
\hline & & $\begin{array}{l}\text { Stagnicola palustris } \\
\text { (O. F. Müller, 1774) }\end{array}$ & & & & & & & & & & & & & 9 & 0.8 & 6 & 0.2 \\
\hline & Planorbidae & $\begin{array}{l}\text { Anisus spirorbis } \\
\text { (Linnaeus, 1758) }\end{array}$ & & & & & & & & & 2 & 0.2 & 4 & 0.4 & 2 & 0.2 & 13 & 0.5 \\
\hline \multirow{3}{*}{$\begin{array}{l}\text { Bivalvia } \\
\text { Crustacea }\end{array}$} & Sphaeriidae & & 24 & 1.0 & 28 & 1.3 & 33 & 1.5 & 37 & 1.2 & 35 & 3.9 & 29 & 2.9 & 63 & 5.3 & 52 & 1.9 \\
\hline & Gammaridae & $\begin{array}{c}\text { Gammarus fossarum } \\
\text { Koch, } 1836\end{array}$ & 1123 & 48.1 & 943 & 45.3 & 1073 & 48.3 & 1358 & 45.8 & 51 & 5.6 & 58 & 5.7 & 67 & 5.6 & 65 & 2.4 \\
\hline & Asellidae & $\begin{array}{l}\text { Asellus aquaticus } \\
\text { (Linnaeus, 1758) }\end{array}$ & 5 & 0.2 & 6 & 0.3 & 4 & 0,2 & 7 & 0.2 & 3 & 0.3 & 4 & 0.4 & 2 & 0.2 & 3 & 0.1 \\
\hline \multirow{4}{*}{$\begin{array}{l}\text { Oligochaeta } \\
\text { Hirudinea } \\
\text { Plecoptera } \\
\text { Trichoptera }\end{array}$} & & & 7 & 0.3 & 8 & 0.4 & 10 & 0.4 & 12 & 0.4 & 16 & 1.8 & 18 & 1.8 & 13 & 1.1 & 15 & 0.6 \\
\hline & Erpobdellidae & & & & & & & & & & & & 1 & 0.1 & & & 1 & 0.04 \\
\hline & Nemouridae & & 3 & 0.1 & 2 & 0.1 & 2 & 0.1 & 2 & 0.1 & & & & & & & 1 & 0.04 \\
\hline & $\begin{array}{l}\text { Limnephilidae } \\
\text { Hydroptilidae }\end{array}$ & & 186 & 8.0 & 240 & 11.5 & 203 & 9.1 & 284 & 9.6 & 23 & 2.5 & 24 & 2.4 & 23 & 1.9 & $\begin{array}{l}25 \\
12\end{array}$ & $\begin{array}{l}0.9 \\
0.4\end{array}$ \\
\hline \multirow[t]{2}{*}{ Coleoptera } & Haliplidae & & & & & & & & & & 3 & 0.3 & 4 & 0.4 & 4 & 0.3 & 2 & 0.1 \\
\hline & Elmidae & & 3 & 0.1 & 2 & 0.1 & 3 & 0.1 & 2 & 0.1 & 5 & 0.6 & 3 & 0.3 & 4 & 0.3 & 4 & 0.1 \\
\hline $\begin{array}{c}\text { Odonata } \\
\text { Megaloptera }\end{array}$ & Coenagrionidae & & & & & & & & & & & & & & & & 1 & 0.04 \\
\hline \multirow{3}{*}{$\begin{array}{l}\text { Megaloptera } \\
\text { Diptera }\end{array}$} & Sialidae & & 25 & 11 & 27 & 13 & 29 & 12 & 28 & 0 & 160 & 187 & 151 & 140 & 171 & 143 & $\begin{array}{c}1 \\
164\end{array}$ & 0.04 \\
\hline & Ceratopogonidae & & 20 & 1.1 & 27 & 1.3 & 29 & 1.3 & 28 & 0.9 & 169 & 18.7 & 151 & 14.9 & $1 / 1$ & 14.3 & $\begin{array}{l}164 \\
1\end{array}$ & $\begin{array}{l}0.1 \\
0.04\end{array}$ \\
\hline & Stratiomyidae & & & & & & & & & & & & & & & & 1 & 0.04 \\
\hline \multirow{2}{*}{\multicolumn{3}{|c|}{$\begin{array}{l}\text { Turbellaria } \\
\text { Number of macroinvertebrates }\end{array}$}} & 15 & 0.6 & 16 & 0.8 & 12 & 0.5 & 18 & 0.6 & & & & & & & & \\
\hline & & & \multirow{2}{*}{\multicolumn{2}{|c|}{$\begin{array}{c}2337 \\
18,696\end{array}$}} & \multicolumn{2}{|c|}{2080} & \multicolumn{2}{|c|}{2223} & \multicolumn{2}{|c|}{2962} & \multicolumn{2}{|c|}{905} & \multicolumn{2}{|c|}{1016} & \multicolumn{2}{|c|}{1200} & \multicolumn{2}{|c|}{2674} \\
\hline \multicolumn{3}{|c|}{ Density of macroinvertebrates (ind $\mathrm{m}^{-2}$ ) } & & & 16 & & 17,7 & & 23,69 & & 724 & & 812 & & 96 & & 21,3 & \\
\hline
\end{tabular}

At the springbrook, seventeen families and one higher taxa (Oligochaeta) were found. Gastropods were the most dominant group and comprised from $66.3 \%$ to $87 \%$ of all of the benthic macroinvertebrates, and among them, P. antipodarum prevailed (Table 3 ). There was a noticeable increase in the density of this alien species in the fourth year of the study. It increased from 4632 to 18,424 individuals per $\mathrm{m}^{2}$ between 2012 and 2015 (Figure 2). The share of P. antipodarum in the community increased from $64.0 \%$ in 2012 to more than $86.1 \%$ in 2015 (Table 3). On the contrary, during the four year study period, the density of B. cf. austriaca decreased from 152 individuals per square meter in 2012 to 32 individuals per square meter in 2015, respectively. On the other hand, the density of other invertebrates did not change noticeably (Figure 2).

The results of the NMDS analysis, which was based on the taxonomic composition of benthic fauna, showed differences between the samples that were collected at the springhead and the samples that were collected at the springbrook. The stress value of the ordination was 0.000413 . The first strong axis (eigenvalue 0.9194 ) grouped the samples 
from the springhead on the left side, whereas the samples from the springbrook were located on the right side (Figure 3). The first axis was positively correlated with water temperature (Table 4). Bythinella cf. austriaca, Gammaridae (Gammarus fossarum Koch, 1836), Asellidae (Asellus aquaticus (Linnaeus, 1758)), Nemouridae, Limnephilidae and Turbellaria were negatively correlated with axis 1 (Table 4), thus demonstrating their preference for colder water. The other axes were distinctly weaker (eigenvalue of axis 20.0536 , eigenvalue of axis 30.0270 ).

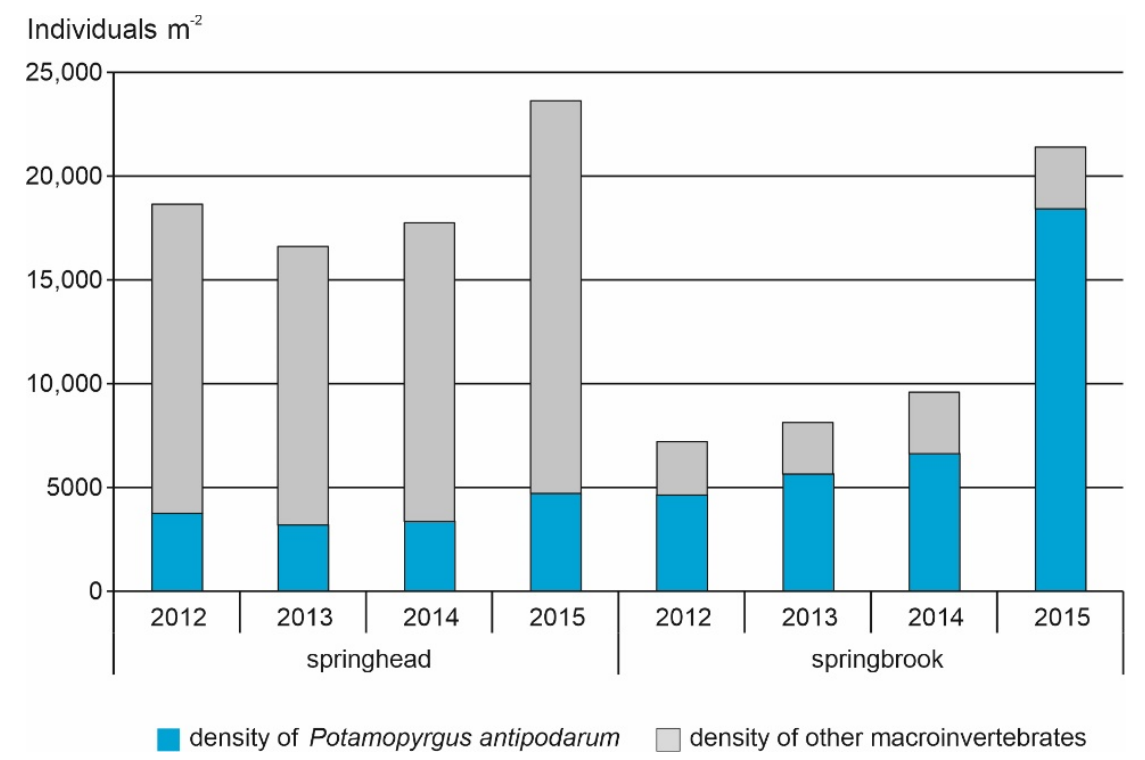

Figure 2. Density of Potamopyrgus antipodarum and other macroinvertebrates at the sampling areas during the study period.

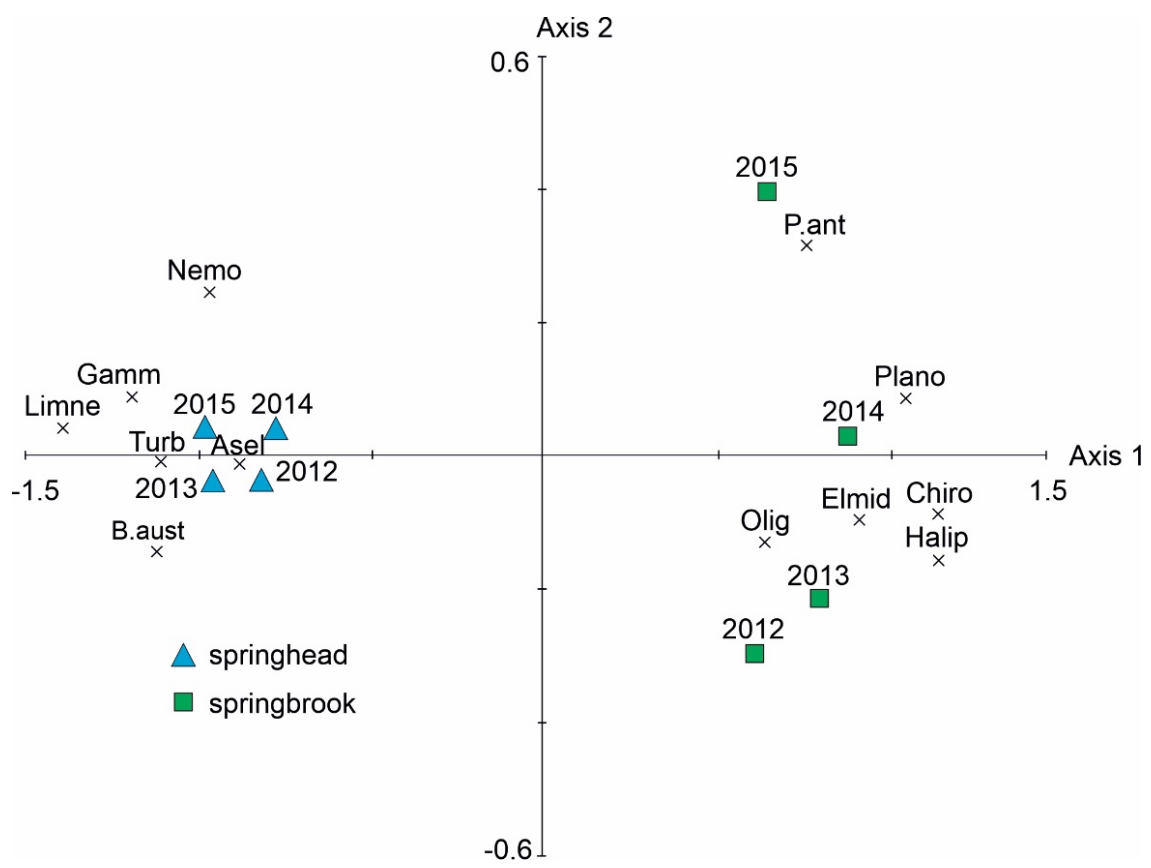

Figure 3. Non-metric multidimensional scaling (NMDS) ordination of the macroinvertebrate taxa at the studied spring ecosystem. Taxa codes: Asel-Asellidae, B.aust-Bythinella cf. austriaca, Chiro-Chironomidae, Elmid-Elmidae, Gamm-Gammaridae, Halip-Haliplidae, LimneLimnephilidae, Nemo—Nemouridae, Olig-Oligochaeta, Plano-Planorbidae, P.ant—Potamopyrgus antipodarum, Turb-Turbellaria. 
Table 4. Statistically significant correlation coefficients between the macroinvertebrate taxa, environmental variable and the NMDS axis 1.

\begin{tabular}{cc}
\hline Taxa & Axis 1 \\
\hline Potamopyrgus antipodarum & $0.8491^{* *}$ \\
Bythinella cf. austriaca & $-0.9898^{* * *}$ \\
Planorbidae & $0.9643^{* * *}$ \\
Gammaridae & $-0.9853^{* * *}$ \\
Asellidae & $-0.8287^{*}$ \\
Oligochaeta & $0.8230^{*}$ \\
Nemouridae & $-0.8361^{* *}$ \\
Limnephilidae & $-0.9882^{* * *}$ \\
Haliplidae & $0.9851^{* * *}$ \\
Elmidae & $0.7649^{*}$ \\
Chironomidae & $0.9938^{* * *}$ \\
Turbellaria & $-0.9937^{* * *}$ \\
Water temperature & $0.9460^{* * *}$ \\
\hline
\end{tabular}

${ }^{*} p<0.05,{ }^{* *} p<0.01,{ }^{* * *} p<0.001$.

\subsection{Characteristic of the Potamopyrgus Antipodarum Populations}

\subsubsection{Size-Class Distribution}

The shell length ranged from $0.6 \mathrm{~mm}$ to $4.7 \mathrm{~mm}$ at the springhead and from $0.6 \mathrm{~mm}$ to $5.1 \mathrm{~mm}$ at the springbrook, respectively. The mean shell length of P. antipodarum was significantly smaller at the first site compared to that at the second in each year of the research period (Table 5). The results of one-way ANOVAs indicated no significant difference in the mean shell length between the years of the study period in both sampling areas (Table 5).

Table 5. Shell length (range and mean) and number of embryos per female of P.antipodarum (range and mean) in the sampling areas and the results of the statistical tests for the effects of the year (one-way ANOVA tests) and localization of site (t-tests).

\begin{tabular}{|c|c|c|c|c|c|c|c|}
\hline \multirow{2}{*}{ Variable } & \multirow{2}{*}{ Site } & \multicolumn{4}{|c|}{ Year } & \multicolumn{2}{|c|}{ One-Way Anova } \\
\hline & & 2012 & 2013 & 2014 & 2015 & F Ratio & $\mathbf{P}$ \\
\hline \multirow{4}{*}{ Shell length (mm) } & \multirow{2}{*}{ springhead } & $0.8-4.7$ & $0.6-4.7$ & $0.7-4.7$ & $0.6-4.7$ & \multirow{3}{*}{1.741} & \multirow{3}{*}{0.157} \\
\hline & & $3.3 \pm 0.8$ & $3.2 \pm 0.9$ & $3.2 \pm 0.9$ & $3.3 \pm 0.9$ & & \\
\hline & \multirow{2}{*}{ springbrook } & $0.7-4.9$ & $0.6-4.9$ & $0.6-5.1$ & $0.6-5.1$ & & \\
\hline & & $4.2 \pm 0.6$ & $4.2 \pm 0.4$ & $4.1 \pm 0.6$ & $4.1 \pm 0.7$ & 2.315 & 0.074 \\
\hline \multirow{8}{*}{$\begin{array}{c}\text { Fecundity } \\
\text { (number of embryos per female) }\end{array}$} & $t$-test & 19.757 & 25.539 & 18.848 & 24.682 & & \multirow{5}{*}{0.106} \\
\hline & \multirow{3}{*}{$\begin{array}{c}p \\
\text { springhead }\end{array}$} & $<0.001$ & $<0.001$ & $<0.001$ & $<0.001$ & \multirow{4}{*}{2.087} & \\
\hline & & 0-36 & $0-34$ & $0-37$ & $0-37$ & & \\
\hline & & $15.4 \pm 12.5$ & $14.5 \pm 11.9$ & $14.9 \pm 12.2$ & $15.2 \pm 12.5$ & & \\
\hline & \multirow{2}{*}{ springbrook } & 0-41 & $0-42$ & 0-39 & $0-42$ & & \\
\hline & & $19.4 \pm 12.7$ & $21.4 \pm 12.3$ & $20.3 \pm 10.3$ & $19.8 \pm 12.1$ & \multirow[t]{3}{*}{1.775} & \multirow[t]{3}{*}{0.156} \\
\hline & $t$-test & 2.377 & 2.585 & 2.159 & 2.025 & & \\
\hline & $p$ & $<0.01$ & $<0.01$ & $<0.01$ & $<0.01$ & & \\
\hline
\end{tabular}

During the period of the field surveys, individuals from tree classes (classes 3, 4 and 5) prevailed in the population of P. antipodarum at the springhead and from one class (class 5 , shell length $>4 \mathrm{~mm}$ ) at the springbrook, respectively (Figure 4 ). 


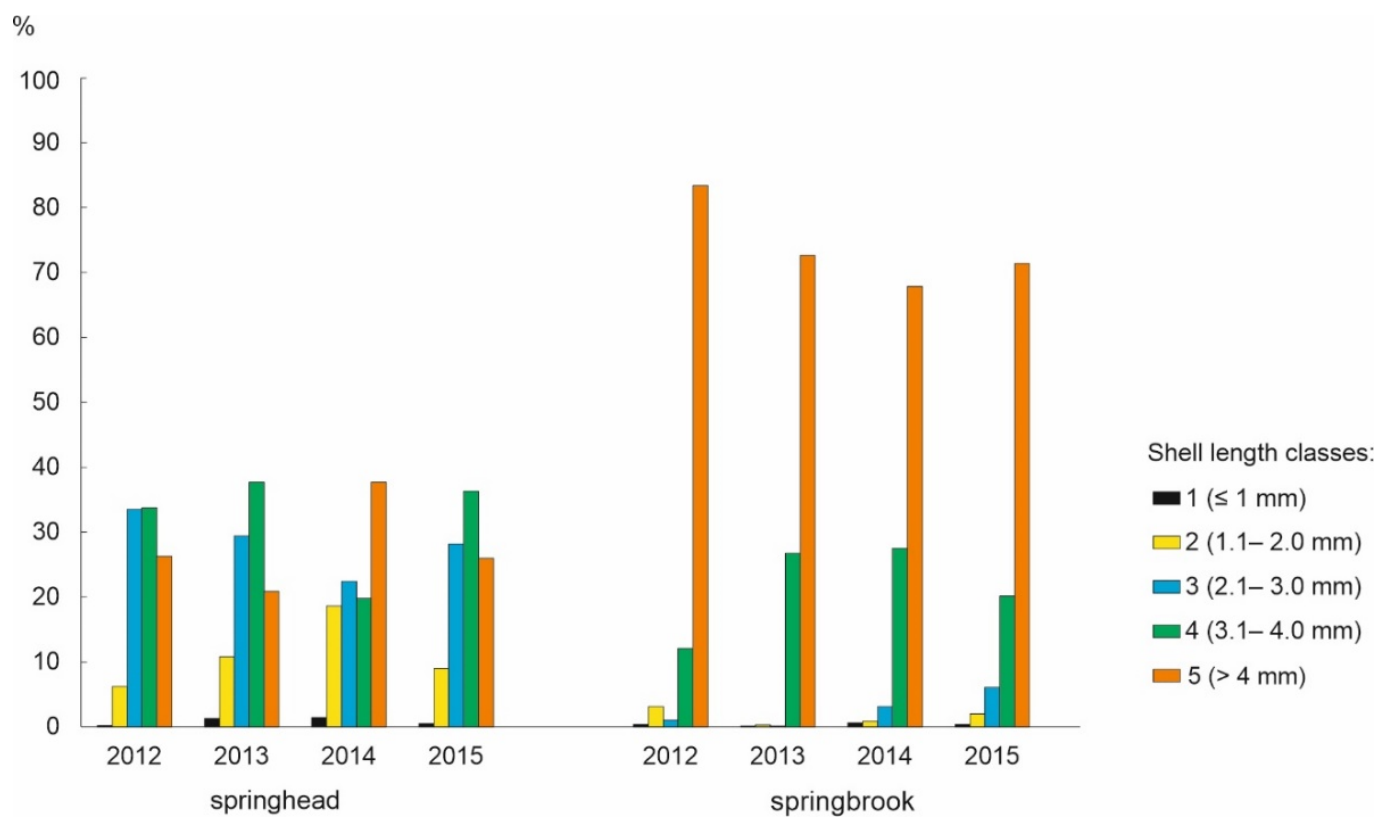

Figure 4. Size (shell length) class distribution of Potamopyrgus antipodarum at the sampling areas during the study period.

\subsubsection{Fecundity of Potamopyrgus Antipodarum}

The population of P. antipodarum that was investigated in our study only consisted of females. They became fecund at a size of more than $3.0 \mathrm{~mm}$ at both sampling sites. At the springhead, embryos were found in snails as small as $3.7 \mathrm{~mm}$, while at the springbrook, embryos were found in snails as small as $3.4 \mathrm{~mm}$. The number of embryos that were carried ranged from 0 to 37 at the springhead and from 0 to 42 at the springbrook, respectively. In the springbrook, the mean number of embryos in a brood pouch was significantly greater compared to that at the springhead in each year of the study period (Table 5). The results of one-way ANOVA showed no significant difference in the mean number of embryos between the years of the research period in both sampling areas (Table 5). The number of embryos in a brood pouch indicated a significant positive correlation with shell length in the Pearson correlation (the springhead: $n=30, \mathrm{R}=0.974, p<0.001$; the springbrook: $n=30, \mathrm{R}=0.980, p<0.001$ )

\section{Discussion}

The discovery of the invasive species P. antipodarum in the spring in southern Poland made it possible to follow the colonization process of cold-water spring ecosystems by this species. For this purpose, we monitored two life history traits, i.e., shell size and fecundity, in two areas of the spring ecosystem. We also analyzed whether there were changes in the structure of the benthic communities following the arrival of New Zealand mud snails.

Our study revealed a small population of $P$. antipodarum in the springhead, with no increase in abundance during the four-year study period (see Figure 2). Conversely, in the springbrook, the population increased almost fourfold in the fourth year of the study compared to the first three years (see Figure 2). Given that the study areas differed with respect to water temperature (the water temperature was about $10^{\circ} \mathrm{C}$ in the springhead and about $14^{\circ} \mathrm{C}$ in the springbrook), we suggest that low temperature may be an important factor limiting the population size of P. antipodarum. Although P. antipodarum tolerates a wide range of temperature from near $0{ }^{\circ} \mathrm{C}$ to $31^{\circ} \mathrm{C}$ and is unable to survive for long periods only at temperatures below freezing, temperature can affect the size of its population [102-104]. Our results are consistent with findings by Hall et al. [105], who found that New Zealand mud snail abundance in the colder Gibbon River, Greater Yellowstone Area, USA, was lower compared with warmer streams. In a stream in southern California, the population 
density of P. antipodarum peaked between $15^{\circ} \mathrm{C}$ and $20^{\circ} \mathrm{C}$ and declined when temperatures exceeded $20^{\circ} \mathrm{C}$ [73].

In our survey, temperature had a positive effect on shell size and fecundity of P. antipodarum. Larger and more fecund snails occurred in the warmer springbrook compared to the colder springhead. Larger snails also brooded significantly more embryos. Our observed positive impact of temperature was consistent with earlier surveys on size $[54,106]$ and fecundity [58,106-108]. As shown by experimental studies [73,109], the positive effect of temperature on life history has an upper limit. The temperature in the studied spring ecosystem was within the tolerance range $[73,110,111]$ and below the upper limit for fecundity [109]. Our study showed that snail shell size was positively correlated with the number of embryos they brooded, as found previously [53,58,106,112,113].

In this study, the populations of $P$. antipodarum were exclusively composed of females. It should be stressed that beyond its native range, males occur very rarely. In Europe, for example, the share of males in populations did not exceed $10 \%[114,115]$; in many countries, no males were found at all [53], and in Poland, only one male has been detected so far [116]. As shown previously [117], invaders that reproduce parthenogenetically have an advantage, as they are not limited by the difficulty of finding a mate, allowing them to establish a viable population during the early stages of colonization.

Our study showed that the abundance of non-native P. antipodarum in the springhead is too low to affect the macroinvertebrates, including native gastropods so far. It is thought that when invader densities are lower than or the same as natives, the negative impact on indigenous species is low [118]. At the springhead, the number of native fauna has not changed significantly. We also did not find any adverse effect on the abundance of native Bythinella cf. austriaca in this place (see Table 3). This Central European snail species [119] lives in high-quality waters that have a constant temperature of around $10^{\circ} \mathrm{C}$ [120]. It has also been observed in small biotopes fed by fresh water with temperatures not exceeding $15^{\circ} \mathrm{C}$, e.g., small ponds, streams and lakes [121]. B. austriaca, like other species of the genus Bythinella, is considered to be a cold-stenothermic species that prefers well-oxygenated environments [122]. Conversely, the research of Klockmann et al. [123] showed that the occurrence and abundance of Bythinella dunkeri was not influenced by temperature, and laboratory experiments revealed its high tolerance toward both high and fluctuating temperatures; therefore, this parameter may not be the critical factor limiting its distribution. This finding may also refer to other species of the genus Bythinella, including B. austriaca, that are ecologically very similar. Although B. austriaca is not nowadays threatened with extinction - it is classified as being of Least Concern (LC), according to the European Red List of Nonmarine Molluscs [119] — threats to springs may directly or indirectly contribute to a decrease in its population. Given that P. antipodarum has inhabited the spring for a relatively short time, we cannot draw conclusions with respect to its impact on benthic fauna. It is difficult to assess whether, with increasing density of the invasive snail, the population size of the spring snail B. cf. austriaca will decrease; thus, further research is required.

Nevertheless, it is important to highlight that the presence of many species, especially endangered or endemic species, in springs is endangered after invasive species settlement, as was the case, for example, of critically endangered red-finned blue-eye in Australian springs [124]. The impact of alien species is magnified in isolated aquatic ecosystems, especially in arid areas devoid of water [125], and they are most harmful in areas with high endemicity of local biota [126]. Once an invasive species is established in a given water body, it can more easily spread to other nearby systems, and the chance of colonization is much greater for nearby populations than those far away [118]. There is a strong need to implement effective management so that promising sites for relocation of endangered species combined with the eradication of invasive species can be identified [124]. According to Davis et al. [25], spring management and removal of alien aquatic species may be more feasible and cost-effective in small springs than for larger aquatic ecosystems. Therefore, their monitoring is very important, which is also confirmed by our research. Taking 
into consideration the above-mentioned threat to springs, monitoring and management measures should be undertaken to preserve and protect these unique environments $[1,7]$. Our study constitutes an important contribution to general knowledge of spring ecology, as well as invasive species, since conservation concern for imperiled invertebrates is growing, but action is stalled by data deficiency, according to Rossini et al. [127].

Author Contributions: Conceptualization, M.K., A.C. and A.S.; methodology, M.K., A.C. and A.S.; investigation, M.K., A.C. and A.S.; writing—original draft preparation, M.K.; writing-review and editing, M.K., A.C. and A.S. All authors have read and agreed to the published version of the manuscript.

Funding: This study was funded by the University of Silesia in Katowice, Poland. This research received no external funding.

Institutional Review Board Statement: Not applicable.

Informed Consent Statement: Not applicable.

Data Availability Statement: The data presented in this study are available on request from the corresponding author.

Acknowledgments: The authors are deeply indebted to the Editor-in-Chief and to the anonymous reviewers for their valuable suggestions and comments, which significantly improved the quality of this manuscript. The authors thank Michele L. Simmons for correcting and improving the language of the manuscript.

Conflicts of Interest: The authors declare no conflict of interest.

\section{References}

1. Cantonati, M.; Gerecke, R.; Bertuzzi, E. Springs of the Alps-Sensitive ecosystems to environmental change: From biodiversity assessments to long-term studies. Hydrobiologia 2006, 562, 59-96. [CrossRef]

2. Scarsbrook, M.; Barquĺn, J.; Gray, D. New Zealand Coldwater Springs and Their Biodiversity; Science for Conservation 278; Department of Conservation: Wellington, New Zealand, 2007.

3. Glazier, D.S. Springs. In Encyclopedia of Inland Waters; Likens, G.E., Ed.; Academic Press Elsevier: Oxford, UK, 2009; Volume 1, pp. 734-755.

4. McCabe, D.J. Biological communities in Springbrooks. In Studies in Crenobiology. The Biology of Springs and Springbrooks; Botosaneanu, L., Ed.; Backhuys Publishers: Leiden, The Netherlands, 1998.

5. Ward, J.V.; Tockner, K. Biodiversity: Towards a unifying theme for river ecology. Freshw. Biol. 2001, 46, 807-819. [CrossRef]

6. Gerecke, R.; Franz, H. Quellen im Nationalpark Berchtesgaden. Lebensgemeinschaften als Indikatoren des Klimawandels; Forschungsbericht 51; Nationalpark Berchtesgaden: Berchtesgaden, Germany, 2006.

7. Cantonati, M.; Fuereder, L.; Gerecke, R.; Juettner, I.; Cox, E.J. Crenic habitats, hotspots for freshwater biodiversity conservation: Toward an understanding of their ecology. Freshw. Sci. 2012, 31, 463-480. [CrossRef]

8. Cantonati, M.; Lange-Bertalot, H.; Scalfi, A.; Angeli, N. Cymbella tridentina sp. nov. (Bacillariophyta), a crenophilous diatom from carbonate springs of the Alps. J. N. Am. Benthol. Soc. 2010, 29, 775-788. [CrossRef]

9. Ilmonen, J; Mykrä, H.; Virtanen, R.; Paasivirta, L.; Muotka, T. Responses of spring macroinvertebrate and bryophyte communities to habitat modification: Community composition, species richness, and red-listed species. Freshw. Sci. 2012, 31, 657-667. [CrossRef]

10. Martin, P.; Brunke, M. Faunal typology of lowland springs in Northern Germany. Freshw. Sci. 2012, 31, 542-562. [CrossRef]

11. Dudgeon, D.; Arthington, A.H.; Gessner, M.O.; Kawabata, Z.; Knowler, D.; Lévêque, C.; Naiman, R.J.; Prieur-Richard, A.H.; Soto, D.; Stiassny, M.L.J.; et al. Freshwater biodiversity: Importance, threats, status, and conservation challenges. Biol. Rev. 2006, 81, 163-182. [CrossRef]

12. Lindegaard, C.; Brodersen, K.P.; Wiberg-Larsen, P.; Skriver, J. Multivariate analyses of macrofaunal communities in Danish springs and Springbrooks. In Studies in Crenobiology: The Biology of Springs and Springbrooks; Botosaneanu, L., Ed.; Backhuys Publishers: Leiden, The Netherlands, 1998.

13. Di Sabatino, A.; Cicolani, B.; Gerecke, R. Biodiversity and distribution of water mites (Acari, Hydrachnidia) in spring habitats. Freshw. Biol. 2003, 48, 2163-2173. [CrossRef]

14. Minckley, W.L. Ecological review and management recommendations for recovery of the endangered Gila topminnow. Great Basin Nat. 1999, 59, 230-244.

15. Ponder, W.F. Endemic aquatic macroinvertebrates of artesian springs of the Great Artesian Basin—Progress and future directions. Rec. South Aus. Mus. 2003, 7, 101-110. 
16. Minckley, W.L.; Unmack, P.J. Western springs: Their faunas, and threats to their existence. In Freshwater Ecoregions of North America; Abell, R.A., Olson, D.M., Dinerstein, E., Hurley, P.T., Diggs, J.T., Eichbaum, W., Walters, S., Wettengel, W., Allnutt, T., Loucks, C., et al., Eds.; Island Press: Washington, DC, USA, 2000.

17. Gervasio, V.; Berg, D.J.; Lang, B.K.; Allan, N.L.; Guttman, S.I. Genetic diversity in the Gammarus pecos species complex: Implications for conservation and regional biogeography in the Chihuahuan Desert. Limnol. Oceanogr. 2004, 49, 520-531. [CrossRef]

18. Meyer, J.L.; Strayer, D.L.; Wallace, J.B.; Eggert, S.L.; Helfman, G.S.; Leonard, N.E. The contribution of headwater streams to biodiversity in river networks. J. Am. Water Resour. Assoc. 2007, 43, 86-103. [CrossRef]

19. Bogan, M.T.; Noriega-Felix, N.; Vidal-Aguilar, S.L.; Findley, L.T.; Lytle, D.A.; GutiérrezRuacho, O.G.; Alvarado-Castro, J.A.; Varela-Romero, A. Biogeography and conservation of aquatic fauna in spring-fed tropical canyons of the southern Sonoran Desert, Mexico. Biodivers. Conserv. 2014, 23, 2705-2748. [CrossRef]

20. Cantonati, M. Diatom communities of springs in the Southern Alps. Diatom Res. 1998, 13, 201-220. [CrossRef]

21. Cantonati, M.; Spitale, D. The role of environmental variables in structuring epiphytic and epilithic diatom assemblages in springs and streams of the Dolomiti Bellunesi National Park (south-eastern Alps). Fundam. Appl. Limnol.—Arch. Hydrobiol. 2009, 174, 117-133. [CrossRef]

22. Cantonati, M.; Lange-Bertalot, H. Diatom biodiversity of springs in the Berchtesgaden National Park (northern Alps, Germany), with the ecological and morphological characterization of two species new to science. Diatom Res. 2010, 25, 251-280. [CrossRef]

23. Barquin, J.; Scarsbrook, M. Management and conservation strategies for coldwater springs. Aquat. Conserv. 2008, 18, 580-591. [CrossRef]

24. Unmack, P.J.; Minckley, W.L. The demise of desert springs. In Aridland Springs in North America: Ecology and Conservation; Stevens, L.E., Meretsky, V.J., Eds.; University of Arizona Press: Tucson, AZ, USA, 2008.

25. Davis, J.A.; Kerezsy, A.; Nicol, S. Springs: Conserving perennial water is critical in arid landscapes. Biol. Conserv. 2017, 211, 30-35. [CrossRef]

26. Boulton, A.J.; Brock, M.A.; Robson, B.J.; Chambers, J.M.; Ryder, D.S.; Davis, J.A. Australian Freshwater Ecology; Wiley-Blackwell: Hoboken, NJ, USA, 2014.

27. Sada, D.W.; Williams, J.E.; Silvey, J.C.; Halford, A.; Ramakka, J.; Summers, P.; Lewis, L. A Guide to Managing, Restoring, and Conserving Springs in the Western United States; Desert Research Institute: Reno, NV, USA, 2001.

28. Ponder, W.F. Desert springs of the Australian Great Artesian Basin. In Proceedings of the Meeting on Spring-Fed Wetlands: Important Scientific and Cultural Resources of the Intermountain Region, Las Vegas, NV, USA, 7-9 May 2002; Sada, D.W., Sharpe, S.E., Eds.; Desert Research Institute: Reno, NV, USA, 2002; pp. 1-13.

29. Young, R.; Crowe, A.; Strickland, R. Ecological Assessments of Spring-Fed Streams on the Wairau Plain; prepared for Marlborough District Council; Cawthron Institute: Nelson, New Zealand, 2002.

30. Fensham, R.J.; Ponder, W.F.; Fairfax, R.J. Recovery Plan for the Community of Native Species Dependent on Natural Discharge of Groundwater from the Great Artesian Basin; Report to Department of the Environment, Water, Heritage and the Arts; Department of Environment and Resource Management: Brisbane, QLD, Australia, 2007.

31. Meffe, G.K.; Hendrickson, D.A.; Minckley, W.L.; Rinne, J.N. Factors resulting in decline of the endangered Sonoran topminnow Poeciliopsis occidentalis (Atheriniformes: Poeciliidae) in the United States. Biol. Conerv. 1983, 25, 135-159. [CrossRef]

32. Rosen, P.C.; Schwalbe, C.R. Bullfrogs: Introduced predators in southwestern wetlands. In Our Living Resources: A Report to the Nation on the Distribution, Abundance, and Health of US; LaRoe, E.T., Farris, G.S., Puckett, C.E., Doran, P.D., Mac, M.J., Eds.; US Department of the Interior-National Biological Service: Washington, DC, USA, 1995.

33. Fairfax, R.; Fensham, R.; Wager, R.; Brooks, S.; Webb, A.; Unmack, P. Recovery of the red-finned blue-eye: An endangered fish from springs in the great Artesian Basin. Wildl. Res. 2007, 34, 156-166. [CrossRef]

34. Kerezsy, A.; Fensham, R. Conservation of the endangered red-finned blue-eye, Scaturiginichthys vermeilipinnis, and control of alien eastern gambusia, Gambusia holbrooki, in a spring wetland complex. Mar. Freshw. Res. 2013, 64, 851-863. [CrossRef]

35. Baillie, J.; Butcher, E. Priceless or Worthless? The World's Most Threatened Species; Zoological Society of London: London, UK, 2012.

36. Minckley, W.L.; Meffe, G.K.; Soltz, D.L. Conservation and management of short-lived fishes: The cyprinodonts. In Battle against Extinction: Native Fish Management in the American West; Minckley, W.L., Deacon, J.E., Eds.; University of Arizona Press: Tucson, AZ, USA, 1991.

37. Pister, E.P. The Desert Fishes Council: Catalyst for change. In Battle against Extinction: Native Fish Management in the American West; Minckley, W.L., Deacon, J.E., Eds.; University of Arizona Press: Tucson, AZ, USA, 1991.

38. Williams, J.E.; Bowman, D.B.; Brooks, J.E.; Echelle, A.A.; Edwards, R.J.; Hendrickson, D.A.; Landye, J.J. Endangered aquatic ecosytems in North American deserts with a list of vanishing fishes of the region. J. AZ-NV Acad. Sci. 1985, 20, 1-62.

39. Contreras-Arquieta, A.; Guajardo-Martinez, G.; Contreras-Balderas, S. Thiara (Melanoides) Tuberculata (Müller, 1774) (Gastropoda: Thiaridae), su Probable Impacto Ecológico en México. Publ. Biol. FCB/UANL 1995, 8, 17-24.

40. Pyšek, P.; Jarošík, V.; Hulme, P.E.; Kühn, I.; Wild, J.; Arianoutsou, M.; Bacher, S.; Chiron, F.; Didžiulis, V.; Essl, F.; et al. Disentangling the role of environmental and human pressures on biological invasions across Europe. Proc. Natl. Acad. Sci. USA 2010, 107, 12157-12162. [CrossRef]

41. Nielson, K.G.; Gill, K.M.; Springer, A.E.; Ledbetter, J.D.; Stevens, L.E.; Rood, S.B. Springs ecosystems: Vulnerable ecological islands where environmental conditions, life history traits, and human disturbance facilitate non-native plant invasions. Biol. Invasions 2019, 21, 2963-2981. [CrossRef] 
42. Mack, R.N.; Lonsdale, W.M. Humans as global plant dispersers: Getting more than we bargained for. Bioscience 2001, 51, 95-102. [CrossRef]

43. Alonso, A.; Castro-Díez, P. The exotic aquatic mud snail Potamopyrgus antipodarum (Hydrobiidae, Mollusca): State of the art of a worldwide invasion. Aquat. Sci. 2012, 74, 375-383. [CrossRef]

44. Collado, G.A. Out of New Zealand: Molecular identification of the highly invasive freshwater mollusc Potamopyrgus antipodarum (Gray, 1843) in South America. Zool. Stud. 2014, 53, 70. [CrossRef]

45. Taybi, A.F.; Mabrouki, Y.; Glöer, P. First record of the New Zealand mudsnail Potamopyrgus antipodarum (J.E. Gray, 1843) (Tateidae, Mollusca) in Africa. Graellsia 2021, 77, e140. [CrossRef]

46. Nentwig, W.; Bacher, S.; Kumschick, S.; Pysěk, P.; Vilà, M. More than "100 worst" alien species in Europe. Biol. Invasions 2018, 20, 1611-1621. [CrossRef]

47. Alonso, A.; Castro-Diez, P. What explains the invading success of the aquatic mud snail Potamopyrgus antipodarum (Hydrobiidae: Mollisca)? Hydrobiologia 2008, 614, 107-117. [CrossRef]

48. Alonso, A.; Castro-Diez, P. Tolerance to air exposure of the new Zealand mudsnail Potamopyrgus antipodarum (Hydrobiidae, Mollusca) as a prerequisite to survival in overland translocation. NeoBiota 2012, 14, 67-74. [CrossRef]

49. Alonso, A.; Valle-Torres, G.; Castro-Díez, P. Survival of an invasive aquatic snail to overland translocation in non-aquatic media: Implications for spreading. Limnologica 2016, 57, 60-65. [CrossRef]

50. Gérard, C.; Blanc, A.; Costil, K. Potamopyrgus antipodarum (Mollusca:Hydrobiidae) in continental aquatic gastropod communities: Impact of salinity and trematode parasitism. Hydrobiologia 2003, 493, 167-172. [CrossRef]

51. Kopp, K.; Jokela, J. Resistant invaders can convey benefits to native species. Oikos 2007, 116, 295-301. [CrossRef]

52. Vinson, M.R.; Baker, M.A. Poor growth of rainbow trout fed New Zealand mud snails Potamopyrgus antipodarum. N. Am. J. Fish. Manag. 2008, 28, 701-709. [CrossRef]

53. Verhaegen, G.; McElroy, K.E.; Bankers, L.; Neiman, M.; Haase, M. Adaptive phenotypic plasticity in a clonal invader. Ecol. Evol. 2018, 8, 4465-4483. [CrossRef]

54. Verhaegen, G.; von Jungmeister, K.; Haase, M. Life history variation in space and time: Environmental and seasonal responses of a parthenogenetic invasive freshwater snail in northern Germany. Hydrobiologia 2021, 848, 2153-2168. [CrossRef]

55. Zbikowski, J.; Zbikowska, E. Invaders of an invader: Trematodes in Potamopyrgus antipodarum in Poland. J. Invertebr. Pathol. 2009, 101, 67-70. [CrossRef]

56. Cichy, A.; Marszewska, A.; Parzonko, J.; Zbikowski, J.; Zbikowska, E. Infection of Potamopyrgus antipodarum (Gray, 1843) (Gastropoda: Tateidae) by trematodes in Poland, including the first record of aspidogastrid acquisition. J. Invertebr. Pathol. 2017, 150, 32-34. [CrossRef]

57. Adema, C.M.; Lun, C.-M.; Hanelt, B.; Seville, R.S. Digenean trematode infections of native freshwater snails and invasive Potamopyrgus antipodarum in the Grand Teton National Park/John D. Rockefeller Memorial Parkway Area. J. Parasitol. 2009, 95, 224-227. [CrossRef]

58. McKenzie, V.J.; Hall, W.E.; Guralnick, R.P. New Zealand mudsnails (Potamopyrgus antipodarum) in Boulder Creek, Colorado: Environmental factors associated with fecundity of a parthenogenic invader. Can. J. Zool. 2013, 91, 30-36. [CrossRef]

59. Gérard, C.; Dussart, G.B.J. Invader and invaded colonisation by, and of, Potamopyrgus antipodarum Gray (Mollusca, Hydrobiidae). In BCPC Symposium Proceedings No 80, Slugs \& Snails: Agricultural, Veterinary and Environmental Perspectives; British Crop Protection Council: Alton, UK, 2003; pp. 281-286.

60. Gérard, C.; Le Lannic, J. Establishment of a new host-parasite association between the introduced invasive species Potamopyrgus antipodarum (Smith) (Gastropoda) an Sanguinicola sp. Plehn (Trematoda) in Europe. J. Zool. 2003, 261, 213-216. [CrossRef]

61. Evans, N.A.; Whitfield, P.J.; Dobson, A.P. Parasite utilization of a host community: The distribution and occurrence of metacercarial cysts of Echinoparyphium recurvatum (Digenea: Echinostomatidae) in seven species of mollusc at Harting Pond, Sussex. Parasitology 1981, 83, 1-12. [CrossRef]

62. Schreiber, E.S.G.; Glaister, A.; Quinn, G.P.; Lake, P.S. Life history and population dynamics of the exotic snail Potamopyrgus antipodarum (Prosobranchia:Hydrobiidae) in Lake Purrumbete, Victoria, Australia. Mar. Freshw. Res. 1998, 49, 73-78. [CrossRef]

63. Schreiber, E.S.G.; Lake, P.S.; Quinn, G.P. Facilitation of native stream fauna by an invading species? Experimental investigations of the interaction of the snail, Potamopyrgus antipodarum (Hydrobiidae) with native benthic fauna. Biol. Invasions 2002, 4, 317-325. [CrossRef]

64. Kerans, B.L.; Dybdahl, M.F.; Gangloff, M.M.; Jannot, J.E. Potamopyrgus antipodarum: Distribution, density, and effects on native macroinvertebrate assemblages in the Greater Yellowstone ecosystem. J. North Am. Benthol. Soc. 2005, 24, 123-138. [CrossRef]

65. Richards, D.C. Competition between the Threatened Bliss Rapids snail, Taylorconcha serpenticola (Hershler et al.) and the Invasive Aquatic Snail, Potamopyrgus antipodarum (Gray). Ph.D. Thesis, Montana State University, Bozeman, MT, USA, 2004.

66. Riley, L.A.; Dybdahl, M.F.; Hall, R.O., Jr. Invasive species impact: Asymmetric interactions between invasive and endemic freshwater snails. J. North. Am. Benthol. Soc. 2008, 27, 509-520. [CrossRef]

67. Collado, G.A.; Aguayo, K.P.; Cazzaniga, N.J.; Gutiérrez Gregoric, D.E.; De Luciá, M.; Haase, M. Systematic evaluation of cryptic freshwater snails from central Chile, including the enigmatic Littoridina santiagensis (Gastropoda, Truncatelloidea). Eur. J. Taxon. 2019, 524, 1-15. [CrossRef] 
68. Collado, G.A.; Vidal, M.A.; Aguayo, K.P.; Méndez, M.A.; Valladares, M.A.; Cabrera, F.J.; Pastenes, L.; Gutiérrez Gregoric, D.E.; Puillandre, N. Morphological and molecular analysis of cryptic native and invasive freshwater snails in Chile. Sci. Rep. 2019, 9, 7846. [CrossRef]

69. Múrria, C.; Bonada, N.; Prat, N. Effects of the invasive species Potamopyrgus antipodarum (Hydrobiidae, Mollusca) on community structure in a small Mediterranean stream. Fundam. Appl. Limnol. 2008, 71, 131-143. [CrossRef]

70. Schmidlin, S.; Schmera, D.; Baur, B. Alien molluscs affect the composition and diversity of native macroinvertebrates in a sandy flat of Lake Neuchâtel, Switzerland. Hydrobiologia 2012, 679, 233-249. [CrossRef]

71. Hall, R.O., Jr.; Tank, J.L.; Dybdahl, M.F. Exotic snails dominate nitrogen and carbon cycling in a highly productive stream. Front. Ecol. Environ. 2003, 1, 407-411. [CrossRef]

72. Arango, C.P.; Riley, L.; Tank, J.L.; Hall, R.O., Jr. Herbivory by an invasive snail increases nitrogen fixation in a nitrogen-limited stream. Can. J. Fish. Aquat. Sci. 2009, 66, 1309-1317. [CrossRef]

73. Bennett, D.M.; Dudley, T.L.; Cooper, S.D.; Sweet, S.S. Ecology of the invasive New Zealand mud snail, Potamopyrgus antipodarum (Hydrobiidae), in mediterranean-climate stream system. Hydrobiologia 2015, 746, 375-399. [CrossRef]

74. Bruce, R.L.; Moffitt, C.M. Survival and passage of ingested New Zealand Mudsnails through the intestinal tract of rainbow trout. N. Am. J. Aquac. 2009, 71, 287-301. [CrossRef]

75. Brenneis, V.E.F.; Sih, A.; de Rivera, C.E. Integration of an invasive consumer into an estuarine food web: Direct and indirect effects of the New Zealand mud snail. Oecologia 2011, 167, 169-179. [CrossRef]

76. Rakauskas, V.; Butkus, R.; Merkyte, E. Consumption of the invasive New Zealand mud snail (Potamopyrgus antipodarum) by benthivorous predators in temperate lakes: A case study from Lithuania. Hydrobiologia 2016, 775, 213-230. [CrossRef]

77. Schreiber, E.S.G.; Quinn, G.P.; Lake, P.S. Distribution of an alien aquatic snail in relation to flow variability, human activity and water quality. Freshw. Biol. 2003, 48, 951-961. [CrossRef]

78. Bodon, M.; Cianfanelli, S.; Montanari, A. Mollusks of the Frasassi karstic complex and adjacent sulfidic spring. In Proceedings of the Frasassi Stygobionts and Their Sulfidic Environment. A Scientific Conference and Workshop: Abstracts, Genga, Italy, 10-13 September 2009; pp. 9-11.

79. Moseley, M. Early British reports of aquatic mollusca living in underground water pipes. Cave Karst. Sci. 2002, 29 , 123-124.

80. Ross, R.M.; Lellis, W.A.; Benett, R.M.; Johnson, C.S. Landscape determinants of nonindigenous fish invasions. Biol. Invasions 2001, 3, 347-361. [CrossRef]

81. Cada, C.A. Interactions between the Invasive New Zealand mudsnail, Potamopyrgus antipodarum, Baetid Mayflies, and Fish Predators. Ph.D. Thesis, University of Montana State, Bozeman, MT, USA, 2004.

82. Richards, D.C.; O'Connell, P.; Shinn, D.C. Simple control method to limit spread of New Zealand mudsnail, Potamopyrgus antipodarum. N. Am. J. Fish. Manag. 2004, 24, 114-117. [CrossRef]

83. Alonso A. Valoración del efecto de la degradación ambiental sobre los macroinvertebrados bentónicos en la cabecera del río Henares. Ecosistemas 2006, 15, 101-105.

84. Hinz, W.; Boeters, H.D.; Guenther, A. On the freshwater mollusc fauna in the Spanish Province of Cuenca. Malakol. Abh. 1994, 17, 65-81.

85. Kerney, M. Atlas of the Land and Freshwater Molluscs of Britain and Ireland; Harley Books Martins, Great Horskesley: Colchester, Essex, UK, 1999.

86. Richards, D.C.; Cazier, L.D.; Lester, G.T. Spatial distribution of three snail species including the invader Potamopyrgus antipodarum in a freshwater spring. West. N. Am. Naturalist 2001, 6, 375-380. Available online: https://www.jstor.org/stable/41717182 (accessed on 5 November 2021).

87. Dumnicka, E.; Galas, J.; Koperski, P. Benthic invertebrates in karst springs: Does substratum or location define communities? Int. Rev. Hydrobiol. 2007, 92, 452-464. [CrossRef]

88. Koperski, P.; Dumnicka, E.; Galas, J. Abiotic parameters determining fauna composition in karstic springs. Pol. J. Ecol. 2011, 59, 153-163.

89. Wilke, T.; Haase, M.; Hershler, R.; Liu, H.-P.; Misof, B.; Ponder, W. Pushing short DNA fragments to the limit: Phylogenetic relationships of 'hydrobioid' gastropods (Caenogastropoda: Rissooidea). Mol. Phylogenet. Evol. 2013, 66, 715-736. [CrossRef]

90. Thienemann, A. Hydrobiologische Untersuchungen an Quellen. Arch. Hydrobiol. 1924, 14, 41.

91. Springer, A.E.; Stevens, L.E. Spheres of discharge of springs. Hydrogeol. J. 2009, 17, 83-93. [CrossRef]

92. Galas, J. Human impact on physical and chemical properties of springs from Cracow-Częstochowa Upland (Southern Poland). Pol. J. Ecol. 2005, 53, 329-341.

93. Erman, N.A.; Erman, D.C. Spring permanence, Trichoptera species richness and the role of drought. J. Kans. Entomol. Soc. 1995, $68,50-64$.

94. Von Fumetti, S.; Nagel, P.; Baltes, B. Where a springhead becomes a springbrook-A regional zonation of springs. Arch. Hydrobiol. 2007, 169, 37-48. [CrossRef]

95. Glöer, P. Mollusca, I. Süsswassergastropoden. Nord- und Mitteleuropas Bestimmungsschlüssel, Lebensweise, Verbreitung; ConchBooks: Hackenheim, Germany, 2002.

96. Eggers, T.O.; Martens, A. A key to the freshwater Amphipoda (Crustacea) of Germany. Lauterbornia 2001, 42, 1-68.

97. Hermanowicz, W.; Dojlido, J.; Dożańska, W.; Koziorowski, B.; Zerbe, J. Fizyczno-Chemiczne Badania Wody i Ścieków; Arkady: Warszawa, Poland, 1999. 
98. Møller, V.; Forbes, V.E.; Depledge, M.H. Influence of acclimation and exposure temperature on the acute toxicity of cadmium to freshwater snail Potamopyrgus antipodarum (Hydrobiidae). Environ. Toxicol. Chem. 1994, 3, 1519-1524. [CrossRef]

99. Richards, D.C. The New Zealand mud snail invades the Western United States. Aquat. Nuis. Species Dig. 2002, 4, 42-44.

100. Gauch, H.G. Noise reduction by eigenvector ordinations. Ecology 1982, 63, 1643-1649. [CrossRef]

101. Ter Braak, C.J.F.; Šmilauer, P. CANOCO Reference Manual and User's Guide: Software for Ordination (Version 5.0); Microcomputer Power: Ithaca, NY, USA, 2012.

102. Moffitt, C.M.; James, C.A. Response of New Zealand mudsnails Potamopyrgus antipodarum to freezing and near-freezing fluctuating water temperatures. Freshw. Sci. 2012, 31, 1035-1041. [CrossRef]

103. Moffitt, C.M.; James, C.A. Dynamics of Potamopyrgus antipodarum infestations and seasonal water temperatures in a heavily used recreational watershed in intermountain North America. Aquat. Invasions 2012, 7, 193-202. [CrossRef]

104. Hamada, K.; Takeda, N.; Tatara, Y.; Ogata, D.; Nakajima, M.; Sonohara, T.; Urabe, M. Habitat Description of Potamopyrgus antipodarum (Caenogastropoda: Hydrobiidae) in Some Areas of Japan: How Far Will It Spread? Venus 2013, 71, 61-79.

105. Hall, R.O., Jr.; Dybdahl, M.F.; VanderLoop, M.C. Extremely high secondary production of introduced snails in rivers. Ecol. Appl. 2006, 16, 1121-1131. [CrossRef]

106. Verhaegen, G.; Neiman, M.; Haase, M. Ecomorphology of a generalist freshwater gastropod: Complex relations of shell morphology, habitat, and fecundity. Org. Divers. Evol. 2018, 18, 425-441. [CrossRef]

107. Dybdahl, M.F.; Kane, S.L. Adaptation vs. phenotypic plasticity in the success of a clonal invader. Ecology 2005, 86, $1592-1601$. [CrossRef]

108. Gust, M.; Buronfosse, T.; André, C.; Mons, R.; Gagné, F.; Garric, J. Is exposure temperature a confounding factor for the assessment of reproductive parameters of New Zealand mudsnails Potamopyrgus antipodarum (Gray)? Aquat. Toxicol. 2011, 101, 396-404. [CrossRef] [PubMed]

109. Macken, A.; Le Page, G.; Hayfield, A.; Williams, T.D.; Brown, R.J. Effects of test design and temperature in a partial life-cycle study with the freshwater gastropod Potamopyrgus antipodarum. Environ. Toxicol. Chem. 2012, 31, 1989-1994. [CrossRef] [PubMed]

110. Winterbourn, M.J. Water temperature as a factor limiting the distribution of Potamopyrgus antipodarum (Gastropoda, Prosobranchia) in the New Zealand thermal region. New Zealand J. Mar. Freshw. Res. 1969, 3, 453-458. [CrossRef]

111. Hylleberg, J.; Siegismund, H.R. Niche overlap in mud snails (Hydrobiidae): Freezing tolerance. Mar. Biol. 1987, 94, 403-407. [CrossRef]

112. Lewin, I. Occurrence of the Invasive Species Potamopyrgus antipodarum (Prosobranchia: Hydrobiidae) in Mining Subsidence Reservoirs in Poland in Relation to Environmental Factors. Malacologia 2012, 55, 15-31. [CrossRef]

113. Coulaud, R.; Mouthon, J.; Quéau, H.; Charles, S.; Chaumot, A. Life-history phenology strongly influences population vulnerability to toxicants: A case study with the mudsnail Potamopyrgus antipodarum. Environ. Toxicol. Chem. 2013, 32, 721-1736. [CrossRef]

114. Wallace, C. On the distribution of the sexes of Potamopyrgus jenkinsi (Smith). J. Mollusc. Stud. 1985, 51, 290-296. [CrossRef]

115. Økland, J. Lakes and Snails; Universal Book Services/Dr. W. Backhuys: Oegstgeest, The Netherlands, 1990.

116. Falniowski, A. A male of Potamopyrgus jenkinsi (Smith, 1889) in Poland. Basteria 1979, 43, $109-111$.

117. Tobin, P.C.; Berec, L.; Liebhold, A.M. Exploiting Allee effects for managing biological invasions. Ecol. Lett. 2011, 14, 615-624. [CrossRef]

118. Havel, J.E.; Kovalenko, K.E.; Thomaz, S.M.; Amalfitano, S.; Kats, L.B. Aquatic invasive species: Challenges for the future. Hydrobiologia 2015, 750, 147-170. [CrossRef]

119. Cuttelod, A.; Seddon, M.; Neubert, E. European Red List of Non-Marine Molluscs; Publications Office of the European Union: Luxembourg, 2011. [CrossRef]

120. Sturm, R. Modelling ecological specifities of freshwater molluscs: The exemplary case of Bythinella austriaca (v. Frauenfeld, 1857) (Gastropoda, Prosobranchia). J. Limnol. 2016, 75, 626-633. [CrossRef]

121. Sturm, R. Malacological mapping in Austria: Distribution of the Austrian spring snail Bythinella austriaca (v. FRAUENFELD, 1857) in the federal state of Salzburg. Linzer. Biol. Beitr. 2018, 50/1, 837-843.

122. Sturm, R. Modelling optimum ranges of selected environmental variables for habitats colonized by the spring snail Bythinella austriaca (v. Frauenfeld, 1857) (Gastropoda, Prosobranchia). Malakol. Abh. 2005, 23, 67-76.

123. Klockmann, M.; Scharre, M.; Haase, M.; Fischer, K. Does narrow niche space in a 'cold-stenothermic'spring snail indicate high vulnerability to environmental change? Hydrobiologia 2016, 765, 71-83. [CrossRef]

124. Nicol, S.; Haynes, T.B.; Fensham, R.; Kerezsy, A. Quantifying the impact of Gambusia holbrooki on the extinction risk of the critically endangered red-finned blue-eye. Ecosphere 2015, 6, 1-18. [CrossRef]

125. Box, J.B.; Duguid, A.; Read, R.; Kimber, R.; Knapton, A.; Davis, J.; Bowland, A. Central Australian waterbodies: The importance of permanence in a desert landscape. J. Arid Environ. 2008, 72, 1395-1413. [CrossRef]

126. Fensham, R.J.; Silcock, J.; Kerezsy, A.; Ponder, W. Four desert waters: Setting arid zone wetland conservation priorities through understanding patterns of endemism. Biol. Conserv. 2011, 144, 2459-2467. [CrossRef]

127. Rossini, R.A.; Fensham, R.J.; Walter, G.H. Determining optimal sampling strategies for monitoring threatened endemic macroinvertebrates in Australia's artesian springs. Mar. Freshw. Res. 2015, 67, 653-665. [CrossRef] 